\title{
A comparative study of five laboratory tests for foeto-placental dysfunction in late pregnancy
}

\author{
D. WATSON, S. A. SIDDIQUI, J. E. H. STAFFORD, S. GIBBARD, AND \\ V. HEWITT
}

From the Area Laboratory, King Edward VII Hospital, Windsor, Berkshire

SYNOPSIS Five foeto-placental function tests were studied in parallel in normal and abnormal late pregnancies with a view to establishing which test or tests is most satisfactorily able to identify the mother whose foetus is in danger.

A critical examination of the levels in blood serum of two enzymes, placental phosphatase iso-enzyme and cystine aminopeptidase, the polypeptide hormone placental lactogen (chorionic음 somatomammotrophin), and the oestrogen oestriol-17 $\beta$ is described.

A correlation was attempted beween clinical data and the results of the above laboratory analyseso and also with the daily urine oestrogen output. The plasma and urine oestriol levels proved generally to be the more useful warning tests in late pregnancy, whilst the plasma cystine aminopeptidase was the least sensitive indicator of foeto-placental dysfunction.

Applying organic chemical analysis, Brown, in 1955, succeeded in producing the first practical and objective test of early foeto-placental dysfunction-the daily urine oestrogen output. Since that time several other clinical chemistry techniques have been developed for the measurement and monitoring of placental function. Urine pregnanediol excretion was one of these early tests. Even though known to be normal in many cases of intrauterine death, pregnanediol assays have only comparatively recently lost favour among some obstetricians. Tests employing blood rather than 24-hr urine collections would seem to have obvious advantages if they are to provide a quick warning or confirmation that the foetus may be in danger. In the present study we looked at the reliability of blood analyses for four substances $^{1}$ - placental phosphatase isoenzyme and cystine aminopeptidase (oxytocinase), placental lactogen (chorionic somatomammotrophin), and oestriol-17 $\beta$. Total oestrogen excretion was also measured. Comparative data were collected for both normal and complicated terminal pregnancies. All results were correlated with the subsequent conditions

'Non-standard abbreviations: h-PL $=$ human placental lactogen; E3 = oestra-1,3,5 (10)-triene-3, 16 $\alpha, 17 \beta$-triol; PA P'ase = placental alkaline phosphatase; $\mathrm{CAS}=$ cystine amino peptidase (nomenclature recommended by the International Union of Biochemistry, J. clin. Path. (1971) 24, 656).

Received for publication 19 February 1973. of the foetus and placenta in order to evaluate the predictive efficacy of the various tests.

\section{Patients}

Women attending antenatal afternoon clinics at two district hospitals volunteered to make part of this용 study possible. Fifty-one women were selected ongrounds of convenience (local residence, etc). Each 3 . donated blood and 24-hr urine specimens before and after delivery. Between four and 10 blood and urine specimens were collected at weekly intervals to termo and two or three specimens at two-weekly intervals $\square$ after delivery.

Of the group studied, 49 produced healthy babies, one delivered a pale infant, unusually shocked at birth (Apgar score 2.2.2.6.8). However, the birth and placental weight were normal and the child subse quently thrived. There had been gross congenitalabnormalities in a previous delivery. Another woman's infant died eight hours after birth, probably due to the respiratory distress syndrome. The placentas? weighed only $230 \mathrm{~g}$.

There were four inductions for postmaturity, alsoo three lower segment casearian sections. Mild to $\overrightarrow{\mathrm{B}}$ moderate foeto-placental dysfunction was assumed in seven instances of macroscopic infarction of the placenta (with or without calcification, grittiness 
etc), and in one case with a low Apgar score after birth.

Additionally, two pregnant women admitted for hypertension, toxaemia, and poor obstetric history were also investigated, and serial blood and urine collections made in the same manner for the analysis of serum placental alkaline phosphatase, placental lactogen, cystine aminopeptidase and oestriol 17- $\beta$, and urine total oestrogens. There was evidence of severe foeto-placental distress in each case. Each showed abnormal dipping of the foetal cardiotocograph. In one a large retroplacental clot was present. The placenta of the other weighed $240 \mathrm{~g}$.

\section{Methods}

All 24-hr urine specimens were analysed for creatinine and total oestrogens and a $10 \mathrm{ml}$ aliquot was stored at $-28^{\circ} \mathrm{C}$ for repeat analyses. During the first year of this study the method of Brown, MacLeod, Macnaughtan, Smith, and Smyth (1968) was used. Later analyses were made by the method of Oakey, Bradshaw, Eccles, Stitch, and Hayes (1967). All blood specimens were centrifuged after $30-40 \mathrm{~min}$, separated, and the serum re-centrifuged. Cell-free sera were stored in plastic pots at $-28^{\circ} \mathrm{C}$ until analysed.

Before determining placental alkaline phosphatase an aliquot of each thawed and well mixed serum was heated in a stoppered tube at $59^{\circ} \mathrm{C} \pm 1^{\circ} \mathrm{C}$ for exactly $30 \mathrm{~min}$. Subsequently, the phosphatase isoenzyme activity was measured at $\mathrm{pH} 10 \cdot 1$ by the method of Kind and King (1954).

Serum placental lactogen was determined in duplicate by radioimmunoanalysis using the reagents and technique supplied by Pharmacia. The procedure is based on that of Letchworth, Boardman, Bristow, Landon, and Chard (1971). Preliminary experiments had shown the results obtained to be comparable though slightly lower than those found using reagents from the Radiochemical Centre, Amersham.

Serum cystine aminopeptidase activity was measured by a modification of the method of Tovey (1969) and recently reported in summary (Watson and Gibbard, 1973). Kinetic measurement of the enzyme is made using Pye Unicam automation equipment AC 60/61 SP 1800 and recorder AR 25.

Serum $(100 \mu \mathrm{l})$ is mixed with $1.0 \mathrm{ml}$ of buffer at pH 7.0 (50 mM $\left.\mathrm{KH}_{2} \mathrm{PO}_{4}-\mathrm{NaOH}\right)$ and $100 \mu \mathrm{l}$ of substrate $(6.0 \mathrm{mmol}$, S-benzyl L-cysteine- 4 ' nitroanilide per litre of 2-methoxyethanol) is added. The reaction rate if followed graphically over a two minperiod beginning one min after the addition of substrate. Increase in absorbance due to p-nitroaniline liberation is measured at $405 \mathrm{~nm}$. The reaction temperature is $30^{\circ} \mathrm{C}$. One $\mathrm{IU} / 1$ produced
$\Delta /$ minute of 0.00082 under test conditions (calculated from the molar extinction coefficient of p-nitroaniline, 9900 ). Therefore $\Delta$ absorbance $/ \mathrm{min} \times 1210$ equals serum cysteine aminopeptidase in IU/1.

Serum oestriol 17- $\beta$ (E3) was estimated by a radioimmunoassay technique also developed in this laboratory. The method is summarized in figure 1.
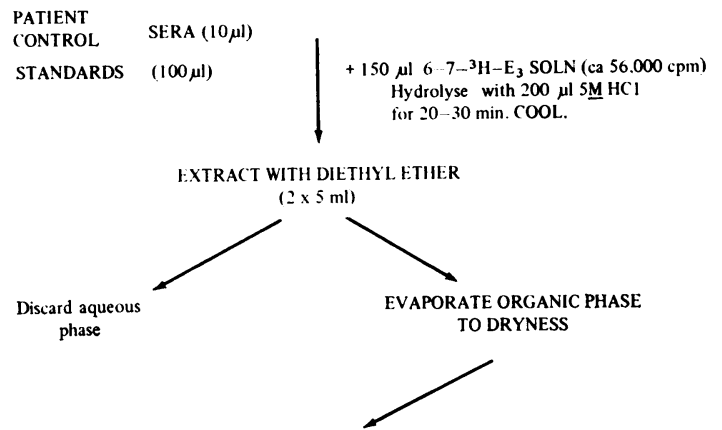

ADD $200 \mu \mathrm{l}$ TRIS/HCl BUFFER (0.1M, pH7.0)

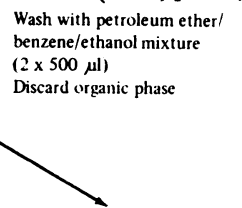

$50 \mu \mathrm{l}$ SAMPLE FOR ESTIMATION OF TOTAL COUNT AND METHOD LOSSES

Fig 1 Flow sheet for determination of serum oestriol by radioimmunoassay $(R I A)$.

For preparation of the standard curve, each final count is corrected for background and expressed as a percentage of the total counts per assay tube. This gives the percentage of bound E3 for each tube. The amount of E3 in each standard and control tube is corrected by multiplying by the recovery factor $(0.627 \pm 4 \%)$. Percentage bound E3 is plotted against mass of E3. The unknown calculated percentage of bound E3 is entered in the graph to give the mass of E3. This ( $\mathrm{pg} / 10 \mu \mathrm{l})$ is then corrected by dividing by the recovery factor and expressed as $\mathrm{ng} / \mathrm{ml}$ serum by multiplying by $0 \cdot 1$. 
Results

\section{RELIABILITY OF ASSAYS}

The heat-stable alkaline phosphatase of one midpregnancy serum was determined 23 times in one morning. The values ranged from 28 to 36 IU/1 with a coefficient of variation of $9 \%$. A similar experiment for cystine aminopeptidase showed a coefficient of variation of $3.6 \%$, range $140-158 \mathrm{IU} / 1$, and for h-PL a $2.0 \%$, range $3 \cdot 7-4.4 \mu \mathrm{g} / \mathrm{ml}$. Serial analyses performed on three patients failed to show any rhythmic variation during a 48-hour period. Typical results in one case are shown in table $I$.

The plasma concentration of oestriol in a control serum was estimated in 10 consecutive radioimmunoassays and the observed coefficient of variation was $7 \cdot 1 \%$ (mean $114 \mathrm{ng} / \mathrm{ml}$ ). Intra-assay variation was estimated by the duplicates method of Snedecor (1962) and for the whole range of oestriol levels encountered was $5.6 \%$.

One urine specimen was analysed as a control with each batch of specimens over a period of one month. The range of oestriol values was $24-32 \mathrm{mg} / 24 \mathrm{hr}$, $\mathrm{SD}=2 \cdot 6$, coefficient of variation $=9 \%$. Over a period of a year, random urine oestriol analyses were checked by independent reference laboratories. The values found in this laboratory were $6,11,20$, and 37 , the mean of 12 results being 19.4 ; the reference values for the same urine samples were $6.2,12.9$, $21 \cdot 1$, and $40 \cdot 4$, the mean of 12 results being $19 \cdot 59 \mathrm{mg}$.

When stored at $-28^{\circ} \mathrm{C}$, the serum h-PL and oestriol content was stable for at least one year and $\stackrel{0}{\vec{*}}$ was uninfluenced by freezing and thawing up to four 을 times. Loss of activity of serum cystine amino- $\vec{F}$ peptidase occurred at $-20^{\circ} \mathrm{C}$. The rate of deterior- $\frac{\rho}{+}$ ation was about $6 \%$ per 10 weeks.

\section{RESULTS IN NORMAL PREGNANCIES}

The mean levels and actual ranges found for serum $\stackrel{\unrhd}{\varrho}$ placental A P'ase, CAS, and h-PLin 34 normal preg- ^ nancies are given in table II. It will be seen that $\overrightarrow{0}$ during late pregnancy the two enzymes show a similar steady increase in concentration, while the $\vec{\omega}$ placental lactogen remains at a fairly constant level. By way of illustration of the latter finding, serum? placental lactogen levels during the last six weeks of $\mathcal{N}^{\circ}$

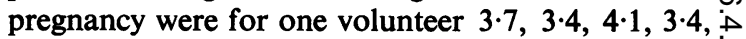
$3 \cdot 6$, and $3 \cdot 4$, and for another $3 \cdot 1,4 \cdot 8,3 \cdot 1,3 \cdot 0,3 \cdot 0$, 응 and $2.7 \mu \mathrm{g} / \mathrm{ml}$.

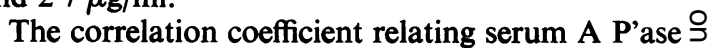
and CAS during the week before delivery was cal- $\rightarrow$ culated to be 0.511 . Correlation between the $\frac{D}{0}$ enzymes can be seen by inspection of table II. No corresponding relation exists between h-PL and $\vec{\varphi}$ either of the enzymes.

The scatter of values in terminal pregnancy is greater for the enzymes than for h-PL, there being a five- to six-fold difference between the lowest and highest serum enzyme values and less than three-fold difference between the lowest and highest serum h-PL level.

The mean 24-hr urine 'oestriol' outputs for un-

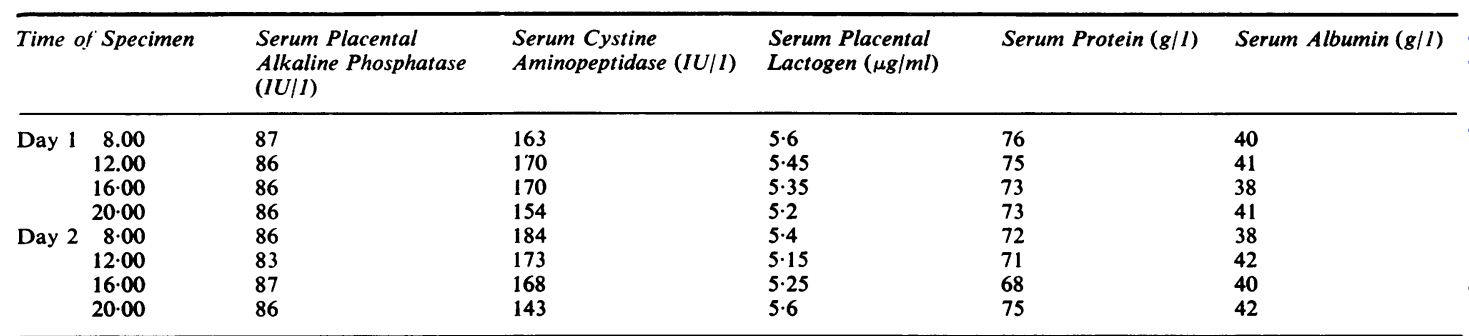

Table I Serum placental A P'ase, $C A S, h-P L$, and proteins in late pregnancy at intervals during two consecutive days

\begin{tabular}{|c|c|c|c|c|c|c|}
\hline & \multicolumn{6}{|c|}{ Weeks before Delivery } \\
\hline & $5-5$ & $4-5$ & $3-4$ & $2-3$ & $1-2$ & $0-1$ \\
\hline $\begin{array}{l}\text { Placental alkaline phosphatase (IU) } \\
\text { Cystine amino-peptidase (IU) } \\
\text { Placental lactogen }(\mu \mathrm{g} / \mathrm{ml})\end{array}$ & $\begin{array}{l}54 \\
(23-109) \\
94 \\
(37-205) \\
4 \cdot 9 \\
(3 \cdot 1-6 \cdot 4)\end{array}$ & $\begin{array}{l}55 \\
(22-102) \\
96 \\
(42-215) \\
5 \cdot 0 \\
(3 \cdot 4-7 \cdot 1)\end{array}$ & $\begin{array}{l}58 \\
(23-126) \\
99 \\
(51-214) \\
5 \cdot 0 \\
(3 \cdot 1-8 \cdot 0)\end{array}$ & $\begin{array}{l}64 \\
(27-134) \\
110 \\
(57-213) \\
5 \cdot 0 \\
(3 \cdot 0-6 \cdot 8)\end{array}$ & $\begin{array}{l}70 \\
(30-137) \\
117 \\
(60-232) \\
5 \cdot 0 \\
(3 \cdot 0-6 \cdot 8)\end{array}$ & $\begin{array}{l}76 \\
(25-124) \\
121 \\
(62-240) \\
5 \cdot 0 \\
(2 \cdot 7-7 \cdot 8)\end{array}$ \\
\hline
\end{tabular}

Table II Serum values (mean and actual ranges) for placental alkaline phosphatase, cystine amino peptidase, and placental lactogen in normal pregnancy (34 women) 


\begin{tabular}{|c|c|c|c|c|c|c|c|c|c|c|c|c|}
\hline \multirow[t]{3}{*}{ Gestation Period in Weeks } & \multicolumn{12}{|c|}{ Foeto-placental Dysfunction } \\
\hline & \multicolumn{8}{|c|}{ Mild-moderate } & \multicolumn{4}{|c|}{ Moderate-severe } \\
\hline & $\mathrm{Cb}$ & $J m$ & $L j$ & $R j$ & $W a$ & $\boldsymbol{W i}$ & $J h$ & Ms & $F m$ & $S w$ & $F j$ & Od \\
\hline $\begin{array}{l}31 \\
32 \\
33 \\
34 \\
35 \\
36 \\
37 \\
38 \\
39 \\
40\end{array}$ & $\begin{array}{l}58 \\
55 \\
62 \\
72 \\
74 \\
77 \\
79\end{array}$ & $\begin{array}{l}23 \\
33 \\
40 \\
38 \\
38 \\
43 \\
45\end{array}$ & $\begin{array}{l}48 \\
32 \\
40 \\
48 \\
60 \\
67 \\
84\end{array}$ & $\begin{array}{l}48 \\
48 \\
57 \\
57 \\
67 \\
65 \\
72\end{array}$ & $\begin{array}{r}89 \\
108 \\
117 \\
122\end{array}$ & $\begin{array}{l}45 \\
70 \\
67 \\
88 \\
90\end{array}$ & $\begin{array}{l}22 \\
20 \\
22 \\
22 \\
36 \\
45\end{array}$ & $\begin{array}{l}27 \\
33 \\
43 \\
33 \\
38 \\
46\end{array}$ & $\begin{array}{l}50 \\
60 \\
76 \\
88 \\
90\end{array}$ & $\begin{array}{l}22 \\
25 \\
25\end{array}$ & $\begin{array}{l}36 \\
40\end{array}$ & $\begin{array}{r}14 \\
17 \\
5 \\
21\end{array}$ \\
\hline
\end{tabular}

Table III Serum placental A-P'ase activities (IU) in 12 cases of foeto-placental dysfunction

\begin{tabular}{|c|c|c|c|c|c|c|c|c|c|c|c|c|}
\hline \multirow[t]{3}{*}{ Gestation Period in Weeks } & \multicolumn{12}{|c|}{ Foeto-placental Dysfunction } \\
\hline & \multicolumn{8}{|c|}{ Mild-moderate } & \multicolumn{4}{|c|}{ Moderate-severe } \\
\hline & $C b$ & $J m$ & $L j$ & $R j$ & $W a$ & $\boldsymbol{W i}$ & $J h$ & Ms & $F m$ & $S w$ & $F j$ & Od \\
\hline $\begin{array}{l}31 \\
32 \\
33 \\
34 \\
35 \\
36 \\
37 \\
38 \\
39 \\
40\end{array}$ & $\begin{array}{l}118 \\
125 \\
123 \\
144 \\
156 \\
165\end{array}$ & $\begin{array}{l}48 \\
63 \\
54 \\
63 \\
60 \\
66\end{array}$ & $\begin{array}{l}114 \\
135 \\
165 \\
154 \\
156\end{array}$ & $\begin{array}{r}84 \\
102 \\
99 \\
105 \\
116 \\
109\end{array}$ & $\begin{array}{l}120 \\
141 \\
144 \\
180 \\
176 \\
192\end{array}$ & $\begin{array}{l}85 \\
87 \\
88 \\
91 \\
93\end{array}$ & $\begin{array}{r}75 \\
81 \\
69 \\
84 \\
105 \\
117\end{array}$ & $\begin{array}{l}103 \\
105 \\
119 \\
132 \\
125 \\
133\end{array}$ & $\begin{array}{c}99 \\
\overline{114} \\
126 \\
144 \\
159\end{array}$ & $\begin{array}{r}111 \\
96 \\
123\end{array}$ & $\begin{array}{l}93 \\
95\end{array}$ & $\begin{array}{l}45 \\
53 \\
48 \\
30\end{array}$ \\
\hline
\end{tabular}

Table IV Serum cystine aminopeptidase level (IU) in 12 cases of foeto-placental dysfunction

\begin{tabular}{|c|c|c|c|c|c|c|c|c|c|c|c|c|}
\hline \multirow[t]{3}{*}{ Gestation Period in W'eeks } & \multicolumn{12}{|c|}{ Foeto-placental Dysfunction } \\
\hline & \multicolumn{8}{|c|}{ Mild-moderate } & \multicolumn{4}{|c|}{ Moderate-severe } \\
\hline & $C b$ & $J m$ & $L j$ & $R j$ & $W a$ & $\boldsymbol{W i}$ & $J h$ & Ms & $F m$ & $S w$ & $F j$ & Od \\
\hline $\begin{array}{l}31 \\
32 \\
33 \\
34 \\
35 \\
36 \\
37 \\
38 \\
39 \\
40\end{array}$ & $\begin{array}{l}4.8 \\
4.9 \\
4.9 \\
4.9 \\
5.1 \\
4.9\end{array}$ & $\begin{array}{l}3.7 \\
5.0 \\
4.7 \\
4.7 \\
4.5\end{array}$ & $\begin{array}{l}6 \cdot 0 \\
5 \cdot 8 \\
5 \cdot 8 \\
5 \cdot 8 \\
6 \cdot 2\end{array}$ & $\begin{array}{l}4.9 \\
5.1 \\
5.1 \\
5.0 \\
5.1\end{array}$ & $\begin{array}{l}4.9 \\
5.6 \\
5.9 \\
6.8 \\
4.6 \\
6.0\end{array}$ & $\begin{array}{l}4.5 \\
4.9 \\
4.4 \\
4.6 \\
4.4\end{array}$ & $\begin{array}{l}4 \cdot 2 \\
4 \cdot 9 \\
5 \cdot 1 \\
5 \cdot 3 \\
5 \cdot 8 \\
6 \cdot 6\end{array}$ & $\begin{array}{l}5 \cdot 6 \\
5 \cdot 5 \\
5 \cdot 3 \\
5 \cdot 2 \\
5 \cdot 3 \\
5 \cdot 1\end{array}$ & $\begin{array}{l}6.2 \\
6.4 \\
6.7 \\
6.5 \\
6.6\end{array}$ & $\begin{array}{l}4 \cdot 2 \\
4 \cdot 4 \\
4 \cdot 8\end{array}$ & $\begin{array}{l}4 \cdot 1 \\
3.8\end{array}$ & $\begin{array}{l}1.7 \\
2 \cdot 1 \\
1.6 \\
1.3\end{array}$ \\
\hline
\end{tabular}

Table $\mathrm{V}$ Serum placental lactogen $(\mu \mathrm{g} / \mathrm{ml})$ in 12 cases of foeto-placental dysfunction

eventful pregnancies were calculated for $34,35 \ldots 39$ weeks as 16 (range 8-28) $\mathrm{mg}, 18(9-34) \mathrm{mg}, 19(9-34)$ $\mathrm{mg}, 21$ (10-39) $\mathrm{mg}, 22$ (11-38) $\mathrm{mg}$, and 24 (11-35) $\mathrm{mg}$.

The corresponding mean plasma oestriol concentrations at weeks $34,35 \ldots 39$ were: 91 (range 38-216), 113 (49-260), 145 (69-308) 147 (64-334), 176 (85-363), and $179(77-413) \mathrm{ng} / \mathrm{ml}$.
RESULTS IN OTHER PREGNANCIES

There were five cases of prolonged, but otherwise normal, pregnancy (42 weeks or more). The serum values measured showed no consistent deviation from the normal.

Mild foeto-placental dysfunction was apparent in eight pregnancies, but of these, only one (Jh) 
showed definite laboratory evidence of abnormality before delivery; tests giving abnormally low results were serum PAP'ase and oestriol and urine oestriol during the period three to six weeks before delivery. The other tests were normal (table III, V).

Of the four cases where foeto-placental dysfunction was more severe, one (Od) showed abnormality in all five tests. Another (Fj) showed low values for serum oestriol doubtful h-PL values, with the other tests normal. The mother (Sw) of the non-surviving infant presented abnormally low figures for the urine oestriol output, serum oestriol, and placental A P'ase, the other tests being normal. In the remaining case (Fm) the only test abnormality found was in the serial serum oestriol levels. These results are shown in tables III-V and figure 2. The degree of correlation between the serum and the urine oestriol values was $r=0.387$ for the normal and $r=0.484$ for the abnormal pregnancies (fig. 3).

\section{Discussion}

The value of a biochemical test in late pregnancy lies in its ability to select for special attention the mother whose foetus is in jeopardy. In this series the serum cystine aminopeptidase (CAS) and the placental A P'ase were the least frequent forecasters of foetoplacental insufficiency. The serum PAP'ase provided warning in two cases and the CAS in only one of $\mathbf{1 2}$ 'abnormal' pregnancies. The positive correlation found between the levels of these substances was not unexpected in view of their common origin of synthesis in the syncytiotrophoblast. However, the wide range of values found for each of the two enzymes in normal terminal pregnancy makes their discriminative use difficult in practice. For example, the term values for CAS were arithmetically distributed in the range 60-240 IU/1 (and similarly for serum PAP'ase at exactly half this level). If one puts the lower CAS limit at $70 \mathrm{IU}$, this will exclude $10 \%$ of the normal pregnancies and bring only one more of the cases with placental infarction into the 'abnormal' category. We considered using a temporary fall in serum activity (in excess of analytical variation) as the indicator of abnormality, but this proved unsatisfactory in its discriminative capacity (see tables III and IV). Thus we have no reason to doubt an earlier finding (Watson, Weston, and Porter, 1965) that the plasma placental A P'ase activity is a poor indicator of placental dysfunction. The other enzyme studied (CAS) proved to be of no prognostic value.

A similar impression emerges when serum h-PL levels are considered, viz, only one of 12 mothers with foeto-placental dysfunction had h-PL values below the lower limit of $3 \mu \mathrm{g} / \mathrm{ml}$ during the five weeks before term (table II). This finding was disappointing in

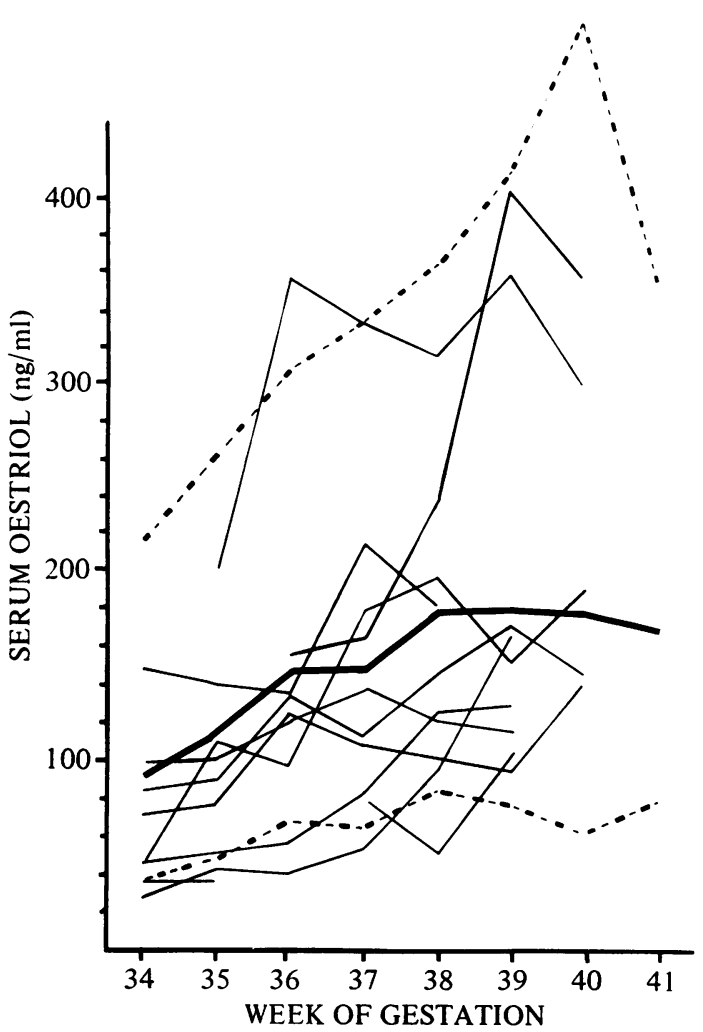

Fig 2 Serum oestriol in 12 cases of foeto-placental inadequacy. Normal values are shown by the thick line (mean values) and the dotted thick and thin lines (2 standard deviation above and below mean values).

view of the greater test sensitivity reported by others (Saxena, Emerson, and Selenkow, 1969; Keller, Baertschi, Bader, Gerber, Schmid, Saltermann, and Kopper, 1971). However, Josimovich, Kosor, Boccella, Mintz, and Hutchinson (1970) were unable to find any correlation between serum h-PL levels and foetal outcome in patients with small-for-dates babies or with toxaemia. While there is no doubt about the existence of a significant correlation between serum h-PL levels and placental weight (Saxena et al, 1969), we think our results reflect the large capacity of the infarcted or abnormally small placenta to continue to produce considerable quantities of h-PL.

A novel feature of the present investigation was

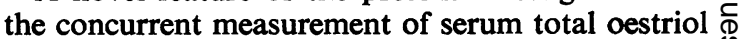
levels. Near term the arithmetic mean serum level of $\stackrel{\oplus}{\rightarrow}$ oestriol was $190 \mathrm{ng} / \mathrm{ml}$ (SD 60) which is similar to 0 the concentrations reported by other workers (table VI) using alternative methods. At each week of gestation the distribution of serum oestriol levels was $\stackrel{\mathbb{D}}{\Omega}$ observed to be logarithmic and the range of normal values ( $\pm 2 \mathrm{SD}$ ) was calculated accordingly (fig 2 ). 


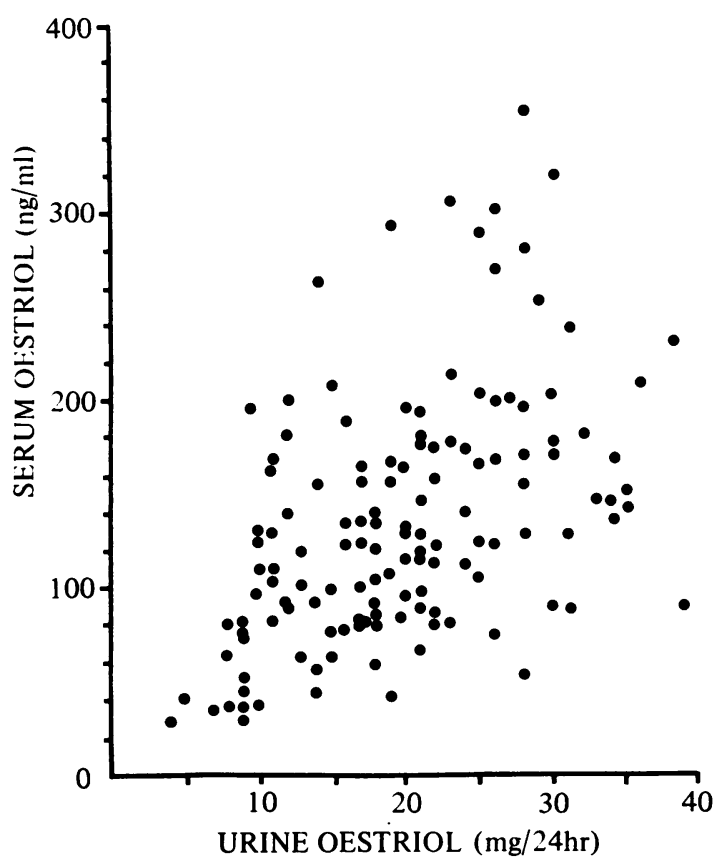

Fig 3 Scattergram of $24 \mathrm{hr}$ urine excretion values and serum oestriol values on each of 131 women during late pregnancy. Normal; $r=0.387, n=88, \mathrm{P}<0.001$ : foeto-placental inadequacy; $r=0.484: n=43, \mathrm{P}<0.001$.

Seven of the eight mild-moderate foeto-placental dysfunction cases had serum oestriol levels within the normal range (fig 2). The exception (Jh) showed abnormally low serum and urine oestriol levels at 34-37 weeks, becoming low normal before caesarian section for placenta praevia at 39 weeks. Each of the four patients with more severe foeto-placental dysfunction presented serum oestriol levels at or below -2SD from the relevant normal mean. However, one of the patients (Sw) at three days before delivery showed a low normal serum E3 level following the previous week's subnormal value. The corresponding urine levels were all subnormal. In another (Fj) a normal excretion of 'oestriol' was observed $(10,10,8$, and $14 \mathrm{mg}$ at $34-35$ weeks) whilst the serum oestriol concentrations were abnormally low ( 36 and $37 \mathrm{ng} / \mathrm{ml}$ ). The lack of total agreement between plasma and urine oestriol levels is demonstrated in figure 3 . The degree of correlation observed in the present study is much lower than that reported by other workers (eg, $r=0.69$, Taylor, Hagerman, Betz, Williams, and Grey 1970). Part of the discrepancy may be the lack of specificity of the urine 'oestriol' method in addition to the observation that each woman exhibits a variable fluctuation in the level of total blood oestriol (Masson and Wilson, 1972). It is thus apparent that with the current assay procedures neither the urine nor the plasma level alone is able to predict all the cases of severe foeto-placental dysfunction.

In conclusion, of the five biochemical parameters studied in late pregnancy, those of placental origin (CAS, PAP'ase, and h-PL) appear to have no prognostic value in cases of mild placental inadequacy. Determination of the maternal blood or urine oestriol-to which the foetus contributesproved to be the better indicator of foeto-placental dysfunction, particularly in the more severe cases. Nevertheless, assuming that infarction reduces placental adequacy then some $60 \%$ of the women with foeto-placental inadequacy did not present abnormal values in any of the tests studied. There would seem to be a pressing need for a more definitive laboratory test of foetal well-being.

We are indebted to Sister M. O. Killingly and Sister K. M. Haynes, Upton Hospital, Slough, and to Miss E. Slade, Midwifery Superintendent, Canadian Memorial Hospital, Taplow, Maidenhead, for their most valuable cooperation. This work was made possible by a grant from the Medical Research Council for two years' assistance, and by a grant for radioactive counting equipment from the Trustees of the Smith, Kline and French Foundation. Dr B. J. A. Furr, University of Reading, kindly gave us the goat oestradiol antiserum. The assistance of Miss E. B. Higley, laboratory aide, is also acknowledged.

\begin{tabular}{llll}
\hline Investigator & Type of Method Used & No. of Women and Single Analyses & Total Oestriol (range, ng/ml) \\
\hline Taylor et al (1970) & Fluorimetric & 4,30 & $50-600$ \\
Nachtigall et al (1971) & Fluorimetric & 22,148 & $100-550$ \\
Cooper et al (1971) & Gas liquid chromatography & 5,24 & $180-510$ \\
Fischer-Rasmussen (1970) & Gas liquid chromatography & 21,134 & $40-300$ \\
Macourt et al (1971) & Comp-prot-binding & 60,400 & $100-320$ \\
Present work & Radioimmunoassay & 34,149 & $63-497$ \\
\hline
\end{tabular}

Table VI Serum total oestriol levels in normal late pregnancy (34-40 weeks) determined by recent non-colorimetric methods 


\section{References}

Brown, J. B. (1955). A chemical method for the determination of oestriol, oestrone and oestradiol in human urine. Biochem $J$., 60, 185-193.

Brown, J. B., MacLeod, S. C., Macnaughtan, C., Smith, M. A., and Smyth, B. (1968). A rapid method for estimating oestrogens in urine using a semi-automatic extractor. J. Endocr., 42, 5-15.

Cooper, W., Coyle, M. G., and Mills, J. A. (1970). Determination of plasma oestriol in normal pregnancy and labour using gasliquid chromatography. $J$. Endocr., 51, 447-454.

Fischer-Rasmussen, W. (1970). Plasma oestriol in normal human pregnancy. J. steroid Biochem., 1, 121-126.

Josimovich, J. B., Kosor, B., Boccella, L., Mintz, D. H., and Hutchinson, D. L. (1970). Placental lactogen in maternal serum as an index of fetal health. Obstet. and Gyneco., 36, 244-250.

Keller, P. J., Baertschi, U., Bader, P., Gerber, C., Schmid, J., Soltermann, R., and Kopper, E. (1971). Biochemical detection of fetoplacental distress in risk pregnancies. Lancet, 2, 729-731.

Kind, P. R. N., and King, E. J. (1954). Estimation of plasma phosphatase by determination of hydrolysed phenol with aminoantipyrine. J. clin. Path., 7, 322-326.

Letchworth, A. T., Boardman, R., Bristow, C., Landon, J., and Chard, T. (1971). A rapid radioimmunoassay for human chorionic somatomammotrophin. J. Obstet. Gynaec. Brit. Cwlth, 78, $\stackrel{\text { 殅 }}{\frac{0}{2}}$ 535-541.

Macourt, D., Corker, C. S., and Naftolin. F. (1971). Plasma oestriol in pregnancy. J. Obstet. Gynaec. Brit. Cwlth, 78, 335-340.

Masson, G. M., and Wilson, G. R. (1972). Variability of total plasma oestriol in late human pregnancy. $J$. Endocr., 54, 245-250.

Nachtigall, L., Bassett, M., Hogsander, U., and Levitz, M. (1971). Plasma estriol levels in normal and abnormal pregnancies: An음 index of fetal welfare. Amer. J. Obstet. Gynec., 101, 638-648.

Oakey, R. E., Bradshaw, L. R. A., Eccles, S. S., Stitch, S. R., and $\overparen{\mathbb{D}}$ Heys, R. F. (1967). The rapid estimation of oestrogens in 0 pregnancy to monitor foetal risk. Clin. chim. Acta, 15, 35-45. Q

Saxena, B. N., Emerson, K., Jr., and Selenkow, H. A. (1969). ${ }^{\mathcal{S}}$ Serum placental lactogen LHPL levels as an index of placental function. New Engl. J. Med., 281, 225-231.

Snedecor, G. W. (1962). Statistical Methods, 6th ed. State University Press, Ames, Iowa.

Taylor, E. S., Hagerman, D. D., Betz, G., Williams, K. L., and Grey P. A. (1970). Estriol concentrations in blood during pregnancy Amer. J. Obstet. Gynec., 108, 868-877.

Tovey, J. E. (1969). Serum oxytocinase. Clin. Biochem., 2, 289-310.

Watson, D., and Gibbard, S. (1973). Automated determination of serum aminopeptidase. Clin. Biochem., 6, 71-2.

Watson, D., Weston, W., and Porter, R. (1965). Plasma alkaline $N$ phosphatases in normal and abnormal terminal pregnancy. $\oplus$ Enzymol. biol. clin. (Basel), 5, 25-28. 